\title{
Comparing PETS and GEPT in China and Taiwan
}

\author{
Mei Wu \\ Leshan Normal University, Leshan 614000, China \\ E-mail: wmayline@yahoo.com; wmayline@gmail.com
}

Received: February 24, 2012

Accepted: March 5, 2012

Published: June 1, 2012

doi:10.5539/elt.v5n6p48

URL: http://dx.doi.org/10.5539/elt.v5n6p48

\begin{abstract}
This paper compares the Public English Test System (PETS) administered in mainland, China and the General English Proficiency Test (GEPT) administered in Taiwan, from the aspects of test levels, test contents and scoring weight. Compared with the PETS, the GEPT is found to value the English productive skills more, and have a greater ability to discriminate the beginner or intermediate learners from the advanced learners.
\end{abstract}

Keywords: Public English Test System (PETS), General English Proficiency Test (GEPT), Test levels, Test contents, Scoring weight

\section{Research Background}

The Public English Test System (PETS) is a 5-level framework of proficiency English examination in mainland, China. It was established to satisfy the requirements of social reform and opening up policies, to help meet the needs of expansion in communications with foreign countries, and to reform the current public English examination in China (PETS Web site, 2012).

The Public English Test System was developed by the National Education Examination Authority (NEEA). This project received financial support from the Department for International Development (DID)-formerly the Overseas Development Administration (ODA) - and technical and professional support from the University of Cambridge Local Examination Syndicate (UCLES). This project is included in the inter-governmental program of Sino-British cultural exchanges (1997-1999) (PETS Web site, 2012).

The Public English Test System has five levels: PETS-1, PETS-2, PETS-3, PETS-4 and PETS-5 (There is a PETS-1B under PETS-1 level.). The first four levels of the Public English Test System delivered their first pilot test in selected cities in 1999 and then in cities all over China in 2003. Test-takers can register for a test at any level corresponding to their English skills, with no restriction on age, profession or academic background.

The General English Proficiency Test (GEPT) is designed and administered by the Language Training and Testing Center (LTTC) to evaluate the English attainment of the general public in Taiwan. The GEPT aims at providing a fair, reliable and effective measurement for learners of English at various levels. The subjects include students and the general public.

The test duration of the General English Proficiency Test (GEPT) varies from 1 hour and 45 minutes for the Elementary level, to 3 hours and 50 minutes for the Superior level. Levels under the Superior level have two stages, and a test-taker must pass the first stage before proceeding to the second. The first stage tests a test-taker's receptive skills, i.e. listening and reading skills; the second stage tests a test-taker's productive skills, i.e. writing and oral English skills. Take the GEPT Advanced level as an example. Test-takers at this level have to score at least 80 out of 120 in both listening and reading in the first stage in order to proceed to the second stage, and the pass mark is set at band 3 for both writing and speaking (Wu \& Lin, 2008: 3). The first three levels administer tests for two times every year, the Advanced level administers tests once every year, and the Superior level is only accessible to a test-taker sponsored by an institution (Roever \& Pan, 2008: 403).

Both of these two tests have received technical support from foreign language assessment experts, such as Cyril Weir, from the University of Cambridge Local Examinations Syndicate (UCLES) in the test design process.

Both tests were created at similar points of time: the PETS started its preparation of documentation in 1998 and delivered its first pilot test in 1999; the GEPT started its preparation of documentation in 1999, delivered the first pilot tests for the first three levels in 2000, and the first pilot tests for the fourth level in 2002 (Gong, 2002: 320). Gong Yin (2002: 318) points out that "a comparative study [between the PETS and the GEPT] can be especially important not only because language testing is a central issue in foreign-language teaching, but also because GEPT 
and PETS are practically designed for people sharing a very similar Chinese culture." Through both documentary and statistical data analysis of the GEPT and the PETS, Gong Yin proved that "there is a real possibility of comparability between GEPT and PETS" (2002: 326). He even discussed "the possibility of their mutual accreditation" (2002: 320).

This study uses the content analysis to compare the GEPT and the PETS from the aspects of test levels, test contents and scoring weight, so as to discover the similarities and dissimilarities of the tests, and their underlying theory of design.

\section{Results \& Discussion}

\subsection{Comparing the Test Levels of the GEPT and the PETS}

By comparing the test levels of the GEPT and the PETS (see Table 1), we knew that these two tests are highly comparable. First of all, both tests examine English ability at five levels, listed from the lowest to the highest. Second, both tests measure equivalent English skills at the first three levels. However, it's worth to note that the Advanced level and the Superior level of the GEPT demand English skills that are much higher than the last two levels of the PETS. More specifically, the test-takers who passed the GEPT Advanced level are expected to possess English skills equivalent to that of an English-majored graduate from a university in Taiwan, or a degree-holder from a university or a graduate school in an English-speaking country. In comparison, the test-takers who passed the PETS-4, which is equivalent to the GEPT Advanced level, are only expected to possess English skills equivalent to that of a non-English major graduate student from a university in China. Furthermore, the test-takers who passed the GEPT Superior level are expected to possess English skills almost equivalent to that of a well-educated native speaker. In comparison, the test-takers who passed the PETS-5, which is equivalent to the GEPT Superior level, are expected to possess English skills almost equivalent to that of a non-English graduate student studying abroad. In a word, the last two levels of the GEPT require test-takers to have a near-native command of English, as the test-takers are supposed to be "professional translators, reporters of international news, diplomats, negotiators in international disputes, or teachers of English" (Chen, 2010: 7).

In addition, the last two levels of the GEPT are much more difficult than the first three levels, while the PETS are not so much different across all 5 levels in terms of their difficulty. For example, the test duration of the first three levels of the GEPT is between 105 minutes and 155 minutes, but the test duration of the last two levels has been extended to 245 minutes and 410 minutes, respectively. Due to the drastic increase in test difficulty from the first three levels to the last two levels, about 150,000 test-takers have taken the first stage test at the Elementary level $(10,000$ test-takers; $59 \%)$ and the Intermediate level (50,000 test-takers; $33 \%)$, while only 899 test-takers (1\%) and only 337 test-takers $(1 \%)$ have taken the first stage test at the Advanced level and at the Superior level, respectively in year 2010 (LTTC Web site, 2010). From this we can conclude that the GEPT is good at discriminating the beginner or intermediate learners from the advanced learners. In contrast, the variance in the test duration of the five levels of the PETS is not great - within the range of 98 minutes and 155 minutes.

\subsection{Comparing the Test Contents of the GEPT and the PETS}

By comparing the test contents of the GEPT and the PETS (see Table 2), we knew that both tests are very similar. They both have four sections: Listening, Reading, Writing and Spoken English. The PETS has one additional section: the Use of English. The PETS is divided into two parts: 1) the written test, which includes listening, the use of English, reading and writing, and 2) the oral test. The GEPT is divided into two parts as well: the first stage and the second stage. The first stage tests receptive skills, i.e. listening and reading, while the second stage tests productive skills, i.e. writing and oral English.

The GEPT does not include the Use of English section that tests vocabulary and grammatical structure.

Compared with the PETS, the GEPT focuses more on productive skills, i.e. writing and spoken English. This can be proved by comparing the time allotment and the skill requirements of these two tests. The time allotted to the writing task in the GEPT varies from 40 minutes to 3 hours, much longer than the 20 to 40 minutes allotted to the writing task in the PETS. The time allotted to the spoken English task in the GEPT varies from 10 to 15 minutes, longer than the 8 to 15 minutes allotted to the spoken English task in the PETS. The emphasis on productive skills is also proved by the skill set required by both tests. For example, the writing section of the GEPT Superior level requires test-takers to summarize and organize the main points from both a listening source and two reading passages, and then integrate these points with his/her opinions into an essay of around 750 words (Chin \& Kuo, 2004: 1), while the PETS only requires test-takers to produce a 250 -word article. The second part of the GEPT Superior level is an integrated but one-on-one interview-type speaking test, which requires an examinee to present the essay he/she writes orally and answer test theme-related questions posed by the interviewer (Chin \& Kuo, 2004: 
1). The oral English section in both the PETS and the GEPT uses forms of testing such as description, question and answer, discussion and so on. However, compared with the PETS, the oral English section in the GEPT has an additional form of testing - the presentation, which is particularly useful for business purposes.

Jessica Wu (2008: 6), a scholar with the Language Training and Testing Center of Taiwan, explained this emphasis of English productive skills in the GEPT when she says the GEPT "was created in response to comments from educators and employers about the general lack of ability to communicate in English among Taiwanese English learners, partly due to the previous 'old-fashioned' approach to English teaching, which over-emphasized the importance of grammatical accuracy."

\subsection{Comparing the Scoring Weight for Test Sections in the GEPT and the PETS}

By comparing the scoring weight for test sections in the GEPT and the PETS (see Table 3), we knew that the scoring weight for the sections in the GEPT (excluding the oral test) remain constant at every level, while the scoring weight for the sections in the PETS (excluding the oral test) either increases or decreases. This means that the skills of English-listening, reading and writing are equally emphasized in the GEPT, while the emphasis on a particular language skill shifts across all five levels in the PETS. The following pattern of change can be observed from various sections in the PETS:

1) Listening section constantly weighs $30 \%$ of the total score in the written tests across five levels. This means that listening is considered an important skill to be measured at every level;

2) The Use of English section examines test-takers' receptive skills such as grammar and vocabulary. The receptive skills are usually stressed at more elementary levels of testing. So it comes as no surprise that the scoring weight of the Use of English section decreases (from the Elementary level to the Superior level: $25 \% \rightarrow 20 \% \rightarrow 15 \% \rightarrow 10 \% \rightarrow 10 \%)$ as the level of testing increases. In another word, the higher the test level is, the smaller the scoring weight is for grammar and vocabulary;

3) Reading skills are productive skills, which are more emphasized at more advanced levels. The scoring weight of the Reading section, therefore, increases (from the Elementary level to the Superior level: $30 \% \rightarrow 30 \% \rightarrow 30 \% \rightarrow 35 \% \rightarrow 35 \%)$ as the level of testing increases. That is to say, the higher the test level is, the bigger the scoring weight is for Reading;

4) Writing skills are productive skills as well. So the scoring weight of the Writing section increases (from the Elementary level to the Superior level: $15 \% \rightarrow 20 \% \rightarrow 25 \% \rightarrow 25 \% \rightarrow 25 \%$ ) as the level of testing increases. That is to say, the higher the test level is, the bigger the scoring weight is for Writing.

\section{Conclusion}

The GEPT administered in Taiwan and the PETS administered in mainland, China are highly comparable. They both measure the English attainment of the general public; they both have five levels, from the Elementary level to the Superior level; and they test not only receptive skills (reading and listening) but also productive skills (writing and speaking).

However, a closer study would reveal more dissimilarity between these two tests. First of all, the GEPT has a greater ability to discriminate the beginner or intermediate learners from the advanced learners, because there's greater variance in the test difficulty across five levels in the GEPT than in the PETS. Though the first three levels of both tests measure equivalent command of English ranging from that of a junior student to a college student, the last two levels of the GEPT are much more difficult than their PETS counterparts.

Secondly, compared with the PETS, the GEPT highly value the productive skills of English (speaking and writing) and somewhat neglects the traditional grammar teaching. The emphasis on the speaking and writing skills in the GEPT can be proved by 1) the much longer test time allotted to the speaking and writing tasks; and 2) the much higher requirements for test-takers' performance in speaking and writing tasks. Different from the GEPT, the PETS relies on changing the scoring weight for three skills of English, i.e. listening, reading and writing, across all five levels to emphasize the productive skills at higher levels of the PETS.

Generally speaking, the GEPT reflects a theory of test design based on the Communicative Approach to English acquisition, while the PETS reflects a lingering effect of the traditional grammar teaching.

Being comparatively easier than their PETS counterparts, the first three levels of the GEPT serve as excellent tests to encourage the beginner learners of English to further their English study. However, the last two levels of the GEPT, which require near-native writing and speaking skills, tells apart the advanced learners of English from the beginner learners. The PETS has less ability to discriminate learners with intermediate language skills from those with advanced language skills. However, with a constant test format across all five levels and a greater proportion of 
objective questions, the PETS is easy to grade and therefore perhaps more effective in testing a much larger population of Chinese test-takers.

\section{References}

Chen, Yuhong. (2010). General English Proficiency Test. Taipei: Hebron Soft, Ltd.

Chin, J., \& Kuo, G. (2004). A Validation Report on the Superior Level GEPT. Paper presented at the 13th International Symposium on English Teaching, Taipei.

Gong, Byron. (2002). Comparative Studies of GEPT and PETS in Taiwan and China, Selected Papers from the Eleventh International Symposium on English Teaching/Fourth Pan-Asian Conference.

Language Training and Testing Center (LTTC). (2010). Some Data Summary for 2010 GEPT. [Online] Available: http://www.lttc.ntu.edu.tw/academics/99GEPT_ScoreR.htm (March 3, 2012)

Language Training and Testing Center (LTTC). (2012). The General English Proficiency Test: Level Descriptors. [Online] Available: http://www.lttc.ntu.edu.tw/E_LTTC/E_GEPT/elementary.htm (March 3, 2012)

Roever, Carsten, \& Pan, Yi-Ching. (2008). GEPT: General English Proficiency Test. Language Testing, 25(3), 403-418.

Web Site of the Public English Test System (PETS). (2012). [An introduction to] The Public English Test System. [Online] Available: http://sk.neea.edu.cn/yydjks/show_sort_3.jsp?class_id=26_12_09 (March 3, 2012)

Web Site of the Public English Test System (PETS). (2012). Description of PETS Levels. Published on 2009/2/12 by the National Education Examinations Authority. [Online] Available: http://sk.neea.edu.cn/yydjks/index.jsp (March 3, 2012)

Wu, J., \& Lin, A. (2008). Assessing English Proficiency at Advanced Level: Testers' Feedback to Teaching. Paper presented at the $25^{\text {th }}$ International Conference of English Teaching and Learning in R. O. C., National Chung Cheng University, Chai-yi.

Wu, J. (2008). Views of Taiwanese Students and Teachers on English Language Testing. Research Notes, 34, 6-9.

\section{Author}

Full name: $\mathrm{Wu}$, Mei

Academic title/degree: Master of Science in Applied Communication Research from College of Communication, Boston University, MA, USA

Working place: College of Foreign Languages, Leshan Normal University, P.R.C.

Title: Assistant Professor

Research field: Teaching English as a Foreign Language, Literature in English Language 
Table 1. Equivalent English Criteria at Each Level of the Public English Test System (PETS) and the General English Proficiency Test (GEPT)

\begin{tabular}{|c|c|c|c|}
\hline Level & $\begin{array}{l}\text { Test } \\
\text { Duration }\end{array}$ & $\begin{array}{l}\text { The General English Proficiency Test } \\
\text { (GEPT) in Taiwan }\end{array}$ & $\begin{array}{l}\text { The Public English Test } \\
\text { System (PETS) in China }\end{array}$ \\
\hline $\begin{array}{l}\text { GEPT Elementary } \\
\text { PETS-1 }\end{array}$ & $\begin{array}{l}105 \mathrm{~min} . \\
98 \mathrm{~min} .\end{array}$ & $\begin{array}{l}\text { a student completing junior } 3 \text { in a middle } \\
\text { school in Taiwan }\end{array}$ & $\begin{array}{l}\text { a student completing junior } 3 \text { in } \\
\text { middle school in China }\end{array}$ \\
\hline $\begin{array}{l}\text { GEPT } \\
\text { Intermediate }\end{array}$ & $130 \mathrm{~min}$. & $\begin{array}{l}\text { A student completing senior } 3 \text { in a middle } \\
\text { school in Taiwan }\end{array}$ & $\begin{array}{l}\text { A student completing senior } 3 \text { in } \\
\text { a middle school in China }\end{array}$ \\
\hline PETS-2 & $130 \mathrm{~min}$. & & \\
\hline $\begin{array}{l}\text { GEPT } \\
\text { High-intermediate }\end{array}$ & $155 \mathrm{~min}$. & $\begin{array}{l}\text { A graduate of non-English major at college } \\
\text { or university in Taiwan }\end{array}$ & $\begin{array}{l}\text { A graduate of non-English } \\
\text { major at college or university in } \\
\text { China }\end{array}$ \\
\hline PETS-3 & $130 \mathrm{~min}$. & & \\
\hline GEPT Advanced & $245 \mathrm{~min}$. & $\begin{array}{l}\text { An English-majored graduate from a } \\
\text { university in Taiwan, or a degree-holder }\end{array}$ & $\begin{array}{l}\text { A non-English major graduate } \\
\text { student from a university in }\end{array}$ \\
\hline PETS-4 & $152 \mathrm{~min}$. & $\begin{array}{l}\text { from a university or a graduate school in an } \\
\text { English-speaking countrv }\end{array}$ & China \\
\hline GEPT Superior & $410 \mathrm{~min}$. & $\begin{array}{l}\text { Almost equivalent to the level of a } \\
\text { well-educated native speaker }\end{array}$ & $\begin{array}{l}\text { Almost equivalent to the level } \\
\text { of a non-English graduate }\end{array}$ \\
\hline PETS-5 & $155 \mathrm{~min}$. & & student studying abroad \\
\hline
\end{tabular}


Table 2. The Public English Test System (PETS) versus the General English Proficiency Test (GEPT) in Terms of Test Contents

\begin{tabular}{|c|c|c|c|c|c|c|}
\hline & \multicolumn{3}{|c|}{ The General English Proficiency Test (GEPT) in Taiwan } & \multicolumn{3}{|c|}{ The Public English Test System (PETS) in China } \\
\hline & Components & Question Types & Test Duration & Components & Question Types & $\begin{array}{l}\text { Test } \\
\text { Duration }\end{array}$ \\
\hline Listening & $\begin{array}{l}3 \text { or } 4 \text { parts for } \\
\text { each level } \\
\text { except for the } \\
\text { Superior level }\end{array}$ & $\begin{array}{l}\text { picture-related } \\
\text { questions; } \\
\text { question \& } \\
\text { answer; short or } \\
\text { long } \\
\text { conversations }\end{array}$ & $20-45 \mathrm{~min}$ & $\begin{array}{l}\text { two parts for level } \\
1-3 \text {; three parts } \\
\text { for level } 4-5 ; 20 \\
\text { to } 30 \text { questions in } \\
\text { total }\end{array}$ & $\begin{array}{l}\text { Sentence } \\
\text { completion; } \\
\text { single-choice } \\
\text { question; true/false } \\
\text { questions; question } \\
\& \text { answer }\end{array}$ & $\begin{array}{l}20-35 \\
\min .\end{array}$ \\
\hline $\begin{array}{l}\text { Use of } \\
\text { English }\end{array}$ & & & & $\begin{array}{l}\text { two parts for level } \\
1-2 ; 20 \text { to } 25 \\
\text { questions in total }\end{array}$ & $\begin{array}{l}\text { single-choice } \\
\text { question; cloze }\end{array}$ & $\begin{array}{l}15-20 \\
\min .\end{array}$ \\
\hline Reading & $\begin{array}{l}2 \text { or } 3 \text { parts for } \\
\text { each level } \\
\text { except for the } \\
\text { Superior level }\end{array}$ & $\begin{array}{l}\text { sentence } \\
\text { completion; } \\
\text { filling out blanks } \\
\text { in a paragraph; } \\
\text { reading; } \\
\text { skimming or } \\
\text { scanning }\end{array}$ & $35-70 \mathrm{~min}$ & $\begin{array}{l}\text { two parts for level } \\
3-4 \text {; three parts } \\
\text { for level } 1 ; 20 \\
\text { questions in total }\end{array}$ & $\begin{array}{l}\text { single-choice } \\
\text { question; } \\
\text { matching; } \\
\text { translation; cloze }\end{array}$ & $\begin{array}{l}30-60 \\
\min .\end{array}$ \\
\hline Writing & $\begin{array}{l}\text { an article of } \\
3000 \text { words for } \\
\text { the Superior } \\
\text { level; shorter } \\
\text { articles for other } \\
\text { levels }\end{array}$ & $\begin{array}{l}\text { sentence writing; } \\
\text { paragraph } \\
\text { writing; } \\
\text { translation; } \\
\text { composition }\end{array}$ & $\begin{array}{l}\text { 40-105 min; } \\
\text { 3-hours writing } \\
\text { for the Superior } \\
\text { level }\end{array}$ & $\begin{array}{l}\text { two parts for level } \\
1-3\end{array}$ & $\begin{array}{l}\text { correction; } \\
\text { note-writing; } \\
\text { sentence } \\
\text { completion; } \\
\text { composition }\end{array}$ & $\begin{array}{l}20-40 \\
\min .\end{array}$ \\
\hline $\begin{array}{l}\text { Spoken } \\
\text { English }\end{array}$ & $\begin{array}{l}\text { three parts for } \\
\text { every level } \\
\text { except for the } \\
\text { Superior level }\end{array}$ & $\begin{array}{l}\text { repetition; reading } \\
\text { aloud; reading; } \\
\text { picture-related } \\
\text { questions; } \\
\text { discussion; } \\
\text { presentation }\end{array}$ & $\begin{array}{l}10-25 \\
\text { min;50-minutes } \\
\text { oral English } \\
\text { test for the } \\
\text { Superior level }\end{array}$ & two or three parts & $\begin{array}{l}\text { Self-introduction; } \\
\text { conversation; } \\
\text { expressing views; } \\
\text { description; } \\
\text { discussing pictures } \\
\text { or words }\end{array}$ & $\begin{array}{l}8-15 \\
\min .\end{array}$ \\
\hline
\end{tabular}

Table 3. The Public English Test System (PETS) versus the General English Proficiency Test (GEPT) in Terms of Scoring Weight*

\begin{tabular}{|c|c|c|c|c|c|c|c|c|c|c|}
\hline & \multicolumn{2}{|c|}{$\begin{array}{l}\text { Elementary } \\
\text { (Level 1) }\end{array}$} & \multicolumn{2}{|c|}{$\begin{array}{l}\text { Intermediate } \\
\text { (Level 2) }\end{array}$} & \multicolumn{2}{|c|}{$\begin{array}{l}\text { High-intermediate } \\
\text { (Level 3) }\end{array}$} & \multicolumn{2}{|c|}{$\begin{array}{l}\text { Advanced } \\
\text { (Level 4) }\end{array}$} & \multicolumn{2}{|c|}{$\begin{array}{l}\text { Superior } \\
\text { (Level 5) }\end{array}$} \\
\hline & PETS & GEPT & PETS & GEPT & PETS & GEPT & PETS & GEPT & PETS & GEPT \\
\hline Listening & $30 \%$ & $35 \%$ & $30 \%$ & $35 \%$ & $30 \%$ & $35 \%$ & $30 \%$ & $35 \%$ & $30 \%$ & ------- \\
\hline Use of English & $25 \%$ & ------- & $20 \%$ & ------- & $15 \%$ & ------- & $10 \%$ & ------- & $10 \%$ & ------- \\
\hline Reading & $30 \%$ & $35 \%$ & $30 \%$ & $35 \%$ & $30 \%$ & $35 \%$ & $35 \%$ & $35 \%$ & $35 \%$ & ------- \\
\hline Writing & $15 \%$ & $30 \%$ & $20 \%$ & $30 \%$ & $25 \%$ & $30 \%$ & $25 \%$ & $30 \%$ & $25 \%$ & NA \\
\hline Total & $100 \%$ & $100 \%$ & $100 \%$ & $100 \%$ & $100 \%$ & $100 \%$ & $100 \%$ & $100 \%$ & $100 \%$ & NA \\
\hline
\end{tabular}

* This is based on the calculation of the proportion of total marks of a GEPT test at its four available levels described in GEPT reports, 2001 \& 2002. The information is cited from Byron Gong's article Comparative Studies of GEPT and PETS in Taiwan and China, 2002. 